\title{
Cytotoxic Potential on Breast Cancer Cells Using Selected Forest Species Found in Malaysia
}

\begin{abstract}
In vitro studies were carried out to evaluate the cytotoxic potential of three selected forest herbaceous species: Tectaria singaporeana (TS), Blechnum orientale (BO) and Tacca integrifolia (TCI). Methanol/methylene chloride extracts of three plant parts viz. leaves, roots and stems were assessed for their cytotoxic potential against human breast cancer cells (MCF-7wt.). Screening of these extracts was done using the microculture, followed by tetrazolium assay after a period of $72 \mathrm{~h}$. There were significant differences between different parts of plants and dilution levels in terms of cytotoxicity, with roots and concentration of $100 \hat{\mathrm{I}} 1 / 4 \mathrm{~g} \mathrm{~mL}-1$ showing the highest cell mortality of 19.58 and $36.59 \%$, respectively. However, the leaves and the stems of all three plant species did not induce any cytotoxic activity on the cells. Overall, the most promising material (IC50<100 $\hat{\mathrm{I}}^{1} 1 / \mathrm{g} \mathrm{mL}-1$ ) were the methanolic extracts from the roots of all three plants. Tectaria singaporeana showed the highest cytotoxic potential with an IC50 value of $28.57 \hat{\mathrm{A}} \pm 11.74 \hat{\mathrm{I}} 1 / 4 \mathrm{~g} \mathrm{~mL}-1$ followed by Blechnum orientale, $32.07 \hat{\mathrm{A}} \pm 7.85 \hat{\mathrm{I}} 1 / 4 \mathrm{~g} \mathrm{~mL}-1$ and Tacca integrifolia, $95.03 \hat{\mathrm{A}} \pm 17.49 \hat{\mathrm{I}} 1 / 4 \mathrm{~g}$ $\mathrm{mL}-1$. From this study, the extracts of these plants may prove to be useful in cancer treatment and prevention.
\end{abstract}

Keyword: Medical plants, Apoptosis, Breast Cancer, Tectaria singaporeana, Blechnum orientale, Tacca integrifolia 